\title{
Glycine Induces Migration of Microglial BV-2 Cells via SNAT-Mediated Cell Swelling
}

\author{
Michael Kittla,b Heidemarie Dobias ${ }^{a, c} \quad$ Marlena Beyreis ${ }^{a}$ Tobias Kiesslich ${ }^{a, e}$ \\ Christian Mayr ${ }^{a, e} \quad$ Martin Gaisberger ${ }^{a, c, d} \quad$ Markus Ritter ${ }^{a, c, d} \quad$ Hubert H. Kerschbaum ${ }^{b}$ \\ Martin Jakaba
}

alnstitute of Physiology and Pathophysiology, Paracelsus Medical University, Salzburg, 'Department of Biosciences, University of Salzburg, Salzburg, 'Gastein Research Institute, Paracelsus Medical University, Salzburg, 'Ludwig Boltzmann Institute for Arthritis and Rehabilitation, Paracelsus Medical University,

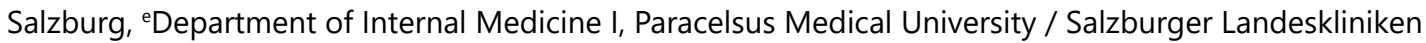
(SALK), Salzburg, Austria

\section{Key Words}

Swelling-dependent chloride current $\cdot \mathrm{Cl}^{-} \cdot \mathrm{ICl}_{\text {swell }} \cdot \mathrm{VRAC} \cdot \mathrm{VSOR} \cdot$ Cell volume regulation • Glycine $\bullet$ Neutral amino acid transporter $\bullet$ Migration $•$ Microglia

\begin{abstract}
Background/Aims: The neutral, non-essential amino acid glycine has manifold functions and effects under physiological and pathophysiological conditions. Besides its function as a neurotransmitter in the central nervous system, glycine also exerts immunomodulatory effects and as an osmolyte it participates in cell volume regulation. During phagocytosis, glycine contributes to (local) cell volume-dependent processes like lamellipodium formation. Similar to the expansion of the lamellipodium we assume that glycine also affects the migration of microglial cells in a cell volume-dependent manner. Methods: Mean cell volume (MCV) and cell migration were determined using flow cytometry and trans-well migration assays, respectively. Electrophysiological recordings of the cell membrane potential $\left(\mathrm{V}_{\text {mem }}\right)$ and swelling-dependent chloride $\left(\mathrm{Cl}^{-}\right)$currents $\left(\mathrm{ICl}_{\text {swell }}\right.$, VSOR, VRAC) were performed using the whole-cell patch clamp technique. Results: In the murine microglial cell line BV-2, flow cytometry analysis revealed that glycine $(5 \mathrm{mM})$ increases the MCV by $~ 9 \%$. The glycine-dependent increase in MCV was suppressed by the partial sodium-dependent neutral amino acid transporter (SNAT) antagonist MeAIB and augmented by the $\mathrm{Cl}^{-}$current blocker DCPIB. Electrophysiological recordings showed that addition of glycine activates a $\mathrm{Cl}^{-}$current under isotonic conditions resembling features of the swelling-activated $\mathrm{Cl}^{-}$current $\left(\mathrm{ICl}_{\text {swell }}\right)$. The cell membrane potential $\left(\mathrm{V}_{\text {mem }}\right)$ displayed a distinctive time course after glycine application; initially, glycine evoked a rapid depolarization mediated by $\mathrm{Na}^{+}$-coupled glycine uptake via SNAT, followed by a further gradual depolarization, which was fully suppressed by DCPIB. Interestingly, glycine significantly increased migration of BV-2 cells, which was suppressed by MeAIB, suggesting that SNAT is involved in the migration process of microglial cells. Conclusion: We conclude




\section{Cellular Physiology Cell Physiol Biochem 2018;50:1460-1473

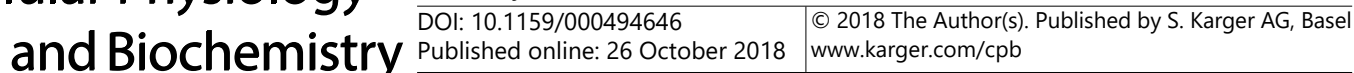 \\ Kittl et al.: Glycine-Induced Migration of Microglial Cells}

that glycine acts as a chemoattractant for microglial cells presumably by a cell volumedependent mechanism involving SNAT-mediated cell swelling.

\section{Introduction}

Glycine is a simple, non-essential neutral amino acid found in all mammalian body fluids. As primarily inhibitory neurotransmitter it is amply present in the central nervous system (CNS) with heterogeneous distribution. Low concentrations are found in the cerebellum and mid-thoracic spinal cord and high concentrations in the ventral horn of the spinal cord and medulla oblongata [1]. Strict control of the extracellular glycine concentration in the CNS is essential for normal neuronal function. During neuronal activity peak glycine concentrations of 2.2-3.5 mM have been monitored in glycinergic synapses [2] and uptake of the transmitter from the extracellular space is mainly accomplished by astrocytes, which store glycine at concentrations up to 3-6 mM [3]. Under pathophysiological conditions like stroke, ischemia and reperfusion injury or neurodegenerative diseases, when glycine is discharged from dying cells, concentrations in the restricted interstitial space may therefore rise substantially. Moreover, glycine levels both in blood and cerebrospinal fluid are increased under clinical conditions like non-ketotic hyperglycinemia [4] and in inflammatory disorders like meningitis [5], amyotrophic lateral sclerosis [6] and multiple sclerosis [7], where the amino acid shows anti-inflammatory effects.

Beside its functions in the CNS, the systemic elevation of glycine in the blood alleviates symptoms of endotoxin-mediated shock [8], alcoholic liver injury [9] and some forms of cancer $[10,11]$. The involvement of glycine in pathophysiological processes in which macrophages play a major role, suggests that it modulates their functions. Effects of glycine on monocytes [12], Kupffer cells [13] or microglial cells $[14,15]$ are mediated either by ionotropic glycine receptors (GlyRs) or by the $\mathrm{Na}^{+}$-dependent neutral amino acid transporter (SNAT; a member of the Slc38 System A amino acid transporter family). In Kupffer cells activation of GlyRs causes a hyperpolarization of the cell membrane potential $\left(\mathrm{V}_{\mathrm{mem}}\right)[13,16]$, whereas a GlyRindependent, but SNAT-dependent effect of glycine appears in microglial cells $[14,15]$. We have shown in microglial cells that glycine uptake via SNAT depolarizes $V_{\text {mem }}$ due to $\mathrm{Na}^{+}$influx, which is unaffected by the GlyR antagonist strychnine, but is inhibited by the specific partial SNAT antagonist $\alpha$-(methylamino)isobutyric acid (MeAIB). Further proof that glycine acts via SNATs rather than GlyRs in microglial cells comes from data showing that the effect of glycine on $\mathrm{V}_{\text {mem }}$ is sensitive to changes in the extracellular $\mathrm{Na}^{+}$-, but not the $\mathrm{Cl}^{-}$concentration. In line with this, reverse-transcriptase PCR did not reveal amplification products of GlyR mRNA/cDNA but revealed SNAT transcripts in primary microglial cells and in the murine cell line BV-2 [14, 15].

In some physiological processes, glycine acts as an organic osmolyte and participates in cell volume (CV) regulation. In mouse embryo cells, intracellular glycine accumulation leads to cell swelling [17-19]. Furthermore, glycine increases CV in Ehrlich ascites tumor cells (EATCs) [20] as well as in microglial cells [15]. In both cell types, $\mathrm{Na}^{+}$free saline inhibits the glycine-induced cell swelling, thus indicating a contribution of SNAT in cell swelling $[15,20]$. The involvement of SNATs in the regulatory volume increase (RVI) process during hypertonic stimulation is well described [21,22]. However, less evidence exists for an involvement of SNAT in cell volume changes under isotonic conditions. Microglial cells are resident immune cells of the CNS. The need for an expansion of cell volume can be observed during migration and phagocytosis of these cells. Under physiological conditions microglial cells have a ramified morphology, with a small soma and elaborated thin processes. This appearance has been associated with and termed as the microglial "resting" state. Upon any detection of neuronal damage, nervous system dysfunctions or brain lesion, a complex activation process happens, and microglial cells undergo morphological changes by retracting their processes and increasing the size of their cell bodies, i.e. cell swelling. Once activated, they are able to migrate to the site of brain injury and phagocytose affected cells or fragments thereof [23]. 


\section{Cellular Physiology Cell Physiol Biochem 2018;50:1460-1473 \begin{tabular}{l|l|l} 
and Biochemistry Published onlIne: 26 October 2018 & $\begin{array}{l}\text { (c) } 2018 \text { The Author(s). Published by S. Karger AG, Basel } \\
\text { www.karger.com/cpb }\end{array}$ \\
\hline
\end{tabular}}

Kittl et al.: Glycine-Induced Migration of Microglial Cells

Migrating microglial cells undergo cell polarity-dependent CV changes during their movement, which is likely a repetitive cycle of protrusion at the cell front (leading edge or lamellipodium), followed by a retraction of the cell's rear (trailing edge). CV increases during the protrusion of the lamellipodium and decreases during the retraction due to a local water movement across the cell membrane [24-27]. Using the terminology of CV regulation, cell migration can be described as an alternating cycle of regulatory volume increase (RVI) at the leading edge and regulatory volume decrease (RVD) at the trailing edge of the cell. CV is mainly regulated by the ion movement across the cell membrane, accompanied by osmotically obliged water fluxes. CV regulation is therefore critically dependent on the activity of ion channels and transporters [28]. Most of the ion transporters that participate in overall CV regulation are involved also in the migration process [26]. The outward movements of ions like $\mathrm{K}^{+}$and $\mathrm{Cl}^{-}$across ion channels located at the rear part of a migrating cell causes a local RVD process whereas transporters that provoke local RVI are located at the front of the cell and import mainly $\mathrm{Na}^{+}$ions via $\mathrm{Na}^{+} / \mathrm{H}^{+}$transporters (NHEs) and $\mathrm{Na}^{+} / \mathrm{K}^{+} / 2 \mathrm{Cl}^{-}$transporter NKCC1 [29-33]. This suggests that also other $\mathrm{Na}^{+}$coupled transporters like $\mathrm{Na}^{+} /$amino acid cotransporters are likely to be involved in the migrating machinery, and a role for the cotransport of $\mathrm{Na}^{+}$and glycine via SNAT is therefore feasible.

A similar mechanistic explanation has been applied to lamellipodia formation/protrusion during phagocytosis [15]. Accordingly, blockade of a swelling-dependent $\mathrm{Cl}^{-}$current $\mathrm{ICl}_{\text {swell' }}{ }^{\prime}$ $\mathrm{ICl}_{\mathrm{vol}}, \mathrm{VSOR}, \mathrm{VRAC}$ ) prevents the uptake of Ig-coated microspheres and disrupts the formation of lamellipodia [34, 35]. Moreover, hypertonic conditions decrease particle engulfment [36], suggesting that phagocytosis itself and especially the formation of a phagocytic cup is highly dependent on $\mathrm{CV}$ regulation. Importantly, in a previous study we could show that application of glycine rescues the diminished phagocytosis under hypertonic conditions, and that glycine stimulates phagocytosis under isotonic conditions, which is suppressed by MeAIB [15]. These findings strongly suggest that SNAT is involved in phagocytosis. Taken together and based on our previous study [15], we therefore hypothesize that in murine BV-2 microglial cells: (i) glycine increases cell volume via a $\mathrm{Na}^{+}$dependent transport (SNAT); (ii) glycineinduced cell swelling triggers isosmotic RVD by activating a swelling dependent $\mathrm{Cl}^{-}$current $\left(\mathrm{ICl}_{\text {swell }}\right)$; and (iii) glycine acts as a chemoattractant that stimulates microglial cell migration.

\section{Materials and Methods}

\section{Cell culture}

BV-2 cells were cultured in $25 \mathrm{~cm}^{2}$ flask with Dulbecco's Modified Eagle's Medium (DMEM) supplemented with $2,200 \mathrm{mg} / \mathrm{L}$ glucose and $10 \%(\mathrm{v} / \mathrm{v}$ ) fetal calf serum (FCS; Biochrom). BV-2 cells were kept at $37^{\circ} \mathrm{C}$ in a humidified atmosphere of $5 \% \mathrm{CO}_{2}$ (standard culture conditions). Subcultures were established once a week and were used for experiments until passage 30 was reached.

\section{Electrophysiology}

BV-2 cells were seeded on $0.01 \%$ poly-D-lysine (PDL)-coated coverslips (Ø $12 \mathrm{~mm}$ ) and cultured for at least $24 \mathrm{~h}$ in DMEM. Coverslips were transferred to a RC-25 recording chamber and mounted on a Nikon Eclipse TE2000-U inverted microscope. All experiments were performed at room temperature and were recorded in the whole cell (ruptured or perforated) patch clamp mode. Ruptured whole cell mode was achieved by applying a slight suction through the pipette whereas the perforated whole cell configuration was reached by adding $130 \mu \mathrm{M}$ amphotericin B to the pipette solution. Recordings were started as soon as the serial resistance was below $30 \mathrm{M} \Omega$ for the perforated and below $10 \mathrm{M} \Omega$ for the ruptured configuration. Patch electrode resistances were 3-7 M . After establishing the whole cell configuration, cells were superfused with an extracellular solution and data were recorded using an EPC-10 amplifier controlled by PatchMaster software (HEKA). Cell membrane potential $\left(\mathrm{V}_{\text {mem }}\right)$ recordings were performed in the zero-current clamp mode. The intracellular (pipette) solution contained (in mM): $70 \mathrm{~K}_{2} \mathrm{SO}_{4}, 10 \mathrm{NaCl}, 10 \mathrm{KCl}, 4 \mathrm{MgCl}_{2}, 2 \mathrm{CaCl}_{2}, 5$ HEPES free acid, 10 EGTA ( $243 \mathrm{mOsm} / \mathrm{kg}$, pH 7.2 adjusted with $\mathrm{KOH}$ ). The extracellular solution contained (in mM): $140 \mathrm{NaCl}, 5.6 \mathrm{KCl}, 2.5 \mathrm{CaCl}_{2}, 1.5 \mathrm{MgCl}_{2}, 10 \mathrm{HEPES}$ free acid, 4.5 glucose and 5 mannitol (300 mOsm/ 


\section{Cellular Physiology Cell Physiol Biochem 2018;50:1460-1473 \begin{tabular}{ll|l} 
and Biochemistry Published online: 26 October 2018 & $\begin{array}{l}\odot 2018 \text { The Author(s). Published by S. Karger AG, Basel } \\
\text { www.karger.com/cpb }\end{array}$ \\
\hline
\end{tabular}}

Kittl et al.: Glycine-Induced Migration of Microglial Cells

$\mathrm{kg}$, pH 7.4 adjusted with $\mathrm{NaOH})$. $\mathrm{NaCl}$ was reduced by $40 \mathrm{mM}$ to get a hypotonic $(225 \mathrm{mmol} / \mathrm{kg}$ ) extracellular solution and mannitol was iso-osmotically substituted by $1 \mathrm{mM}$ or $5 \mathrm{mM}$ glycine to assess glycine-induced depolarization of $\mathrm{V}_{\text {mem }}$. $\mathrm{Cl}^{-}$currents $\left(\mathrm{ICl}_{\text {swell }}\right)$ were recorded under symmetrical intra- and extracellular $\mathrm{Cl}^{-}$ conditions. The extracellular solution consisted of (in mM): $100 \mathrm{NaCl}, 2.5 \mathrm{CaCl}_{2}, 2.5 \mathrm{MgCl}_{2}, 10 \mathrm{HEPES}$ free acid and 97 mannitol (306mmol/kg, pH 7.2 adjusted with $\mathrm{NaOH}$ ). To assess glycine uptake-dependent $\mathrm{Cl}^{-}$ current activation under isotonic conditions, mannitol was substituted iso-osmotically by $1 \mathrm{mM}$ and $5 \mathrm{mM}$ glycine. The pipette solution contained (in mM): $100 \mathrm{CsCl}, 5 \mathrm{MgCl}_{2}, 10 \mathrm{HEPES}$ free acid, $10 \mathrm{EGTA}, 65$ raffinose, $2 \mathrm{Mg}$-ATP (306 mmol/kg, pH 7.2 adjusted with $\mathrm{CsOH}$ ). The currents were monitored every $10 \mathrm{~s}$ applying 500 $\mathrm{ms}$ voltage ramps from $-100 \mathrm{mV}$ to $+100 \mathrm{mV}$. The holding potential between the ramps was kept at $0 \mathrm{mV}$ to avoid voltage-activated currents. Bath solution exchange was performed with a valve-controlled gravitydriven perfusion system (ALA Scientific Instruments) at a flow rate of 3-5 $\mathrm{ml} / \mathrm{min}$. Osmolalities of intra- and extracellular solutions were measured using a vapour pressure osmometer (Wescor).

\section{Assessment of the mean cell volume (MCV) by flow cytometry}

Subconfluent BV-2 cells were harvested by Trypsin/EDTA after growing for 4-5 days under standard cell culture conditions. To measure the effect of $5 \mathrm{mM}$ extracellular glycine under different conditions, the cell suspension was split into aliquots. Every aliquot was then centrifuged for $5 \mathrm{~min}$ at $200 \times \mathrm{g}$. Immediately before the first measurement (time point 0 ) the pellet was re-suspended in $3 \mathrm{ml}$ extracellular solution, which contained (in mM): $140 \mathrm{NaCl}, 5.6 \mathrm{KCl}, 2.5 \mathrm{CaCl}_{2}, 1.5 \mathrm{MgCl}_{2}, 10 \mathrm{HEPES}$ free acid and 4.5 glucose (295 $\mathrm{mOsm} / \mathrm{kg}$, pH 7.4 adjusted with $\mathrm{NaOH}$ ). Under control conditions, the extracellular solution additionally contained $5 \mathrm{mM}$ mannitol. To assess the effect of glycine in combination with the $\mathrm{Cl}$ blocker DCPIB, we isoosmotically substituted mannitol with (1) $5 \mathrm{mM}$ glycine and with (2) $5 \mathrm{mM}$ glycine and $10 \mu \mathrm{M}$ DCPIB. In a second series of experiments cells were exposed to the extracellular solution in presence of (1) $5 \mathrm{mM}$ glycine, (2) $5 \mathrm{mM}$ MeAIB and (3) $5 \mathrm{mM}$ glycine in combination with $5 \mathrm{mM}$ MeAIB. MeAIB and glycine were again isoosmotically substituted by mannitol (control). The samples of both series were alternately measured every $5 \mathrm{~min}$ over a period of $60 \mathrm{~min}$. Mean cell volume (MCV in fl) was directly measured on a CellLab Quanta SC flow cytometer (Beckman Coulter) employing the Coulter principle for volume assessment, which is based on measuring changes in electrical resistance produced by nonconductive particles suspended in an electrolyte solution. The electronic volume channel was calibrated using $10-\mu \mathrm{m}$ Flow-Check fluorospheres (Beckman-Coulter) by positioning this size bead in channel 200 on the volume scale. 8,000 single cells with a diameter $\geq 10 \mu \mathrm{m}$ and $\leq 18 \mu \mathrm{m}$ were analyzed per sample. For analysis the data of each condition were normalized to the respective control condition.

\section{Cell migration}

BV- 2 cells were starved for 12 hours in a serum-free (SF) medium and subsequently seeded in 24-well inserts (24-well inserts with $0.8 \mu \mathrm{M}$ pores; ThinCert ${ }^{\mathrm{TM}}$; Greiner bio-one) at $1 \times 10^{6}$ cells per well. Inserts were transferred in Cellstar ${ }^{\circledR}$ 24-well plates (Greiner) containing $600 \mu \mathrm{l}$ of SF medium without (control) or with glycine, or glycine plus equimolar MeAIB. As positive control conditions we used medium with $10 \%$ FCS, SF medium containing $0.5 \mu \mathrm{g} / \mathrm{ml}$ lipopolysaccharide (LPS from Escherichia coli; Sigma Aldrich) and SF medium containing $1 \mu \mathrm{M}$ adenosine 5'-triphosphate magnesium salt (Mg-ATP; Sigma Aldrich). Cells were incubated overnight under standard culture conditions. Migrated cells were stained with $8 \mu \mathrm{M}$ Calcein AM viability dye (Thermo Fisher Scientific) for $45 \mathrm{~min}$ and then trypsinized with $500 \mu \mathrm{l} 0.25 \%$ Trypsin/EDTA (Sigma Aldrich) for $15 \mathrm{~min} .200 \mu \mathrm{l}$ of the cell suspension were transferred in black, flat bottom 96-well plates (Sarstedt) and fluorescence at $520 \mathrm{~nm}$ ( $485 \mathrm{~nm}$ excitation) was measured with a Spark multimode reader $^{\circledR}$ (Tecan).

\section{Statistical Analysis}

All data are presented as mean \pm sem (standard error of the means). Statistical analyses were performed using SPSS 18.0 (IBM Corporation) or Prism 7.0 (GraphPad Software). Patch clamp data were analyzed using Fit-Master software (HEKA) and Igor Pro 6 (WaveMetrics). Each experiment was repeated at least three times $(n \geq 3)$. Ordinary or repeated measures one-way ANOVA, paired or unpaired double-sided $t$-tests were used as applicable to calculate the levels of significance. Results were regarded as statistically significant at $\mathrm{p}<0.05$. 


\section{Results}

\section{Glycine-induced cell swelling is SNAT dependent}

Fig. 1 shows that iso-osmotic addition of $5 \mathrm{mM}$ glycine caused cell swelling. After 20 and 60 min of glycine application the mean cell volume (MCV) of BV-2 cells was significantly increased by $6.8 \pm 0.6 \%$ and $7.5 \pm 0.4 \%$, respectively, compared to control conditions in the absence of glycine (Fig. 1A). The time course of glycine-induced cell swelling showed a steep initial increase in $\mathrm{MCV}$ reaching a plateau after $\sim 20 \mathrm{~min}$. In presence of the $\mathrm{Cl}^{-}$channel blocker DCPIB $(10 \mu \mathrm{M})$ cell swelling was significantly augmented compared to the effect of glycine alone, with a volume gain of $9.6 \pm 1.9 \%$ and $14.7 \pm 2.1 \%$ after 20 and $60 \mathrm{~min}$, respectively.

To test if glycine-induced cell swelling is mediated by SNAT, MCV was measured in the presence of the partial SNAT antagonist MeAIB ( $5 \mathrm{mM}$ ). As shown in Fig. 1B, glycine led to an increase in MCV by $10.9 \pm 2.5 \%$ after $60 \mathrm{~min}$, whereas in the presence of MeAIB cell swelling was almost completely prevented with a volume gain of $0.9 \pm 1.3 \%$ after $60 \mathrm{~min}$. MeAIB alone caused only a slight increase in MCV by $2.3 \pm 2.1 \%$ within $60 \mathrm{~min}$, which is consistent with partial inhibition of the transporter.

Hypotonicity activates a $\mathrm{Cl}^{-}$current $\left(\mathrm{ICl}_{\text {swell }}\right)$ and leads to depolarization of the cell membrane potential $\left(V_{\text {mem }}\right)$

In most cells, swelling leads to the activation of distinct volume-regulated $\mathrm{Cl}^{-}$channels which give rise to a typical swelling-activated $\mathrm{Cl}^{-}$current $\mathrm{ICl}_{\text {swell }}$ (VSOR, VRAC). The cellular exit of $\mathrm{Cl}$; other anions and organic osmolytes through these channels is accompanied by the outflow of osmotically obliged water and drives the process of regulatory volume decrease (RVD) designated to counteract hypotonic cell swelling [37, 38]. As shown in Fig. 2A, reduction of the extracellular osmolality by $15 \%$ led to the gradual activation of a $\mathrm{Cl}^{-}$current after a delay of $\sim 5-10 \mathrm{~min}$. This current was outwardly rectifying (Fig. 2A-C), inactivated at constant positive potentials (Fig. 2B) and was reversibly inhibited by the $\mathrm{Cl}^{-}$channel blocker NPPB $(150 \mu \mathrm{M})$ (Fig. 2B-C).

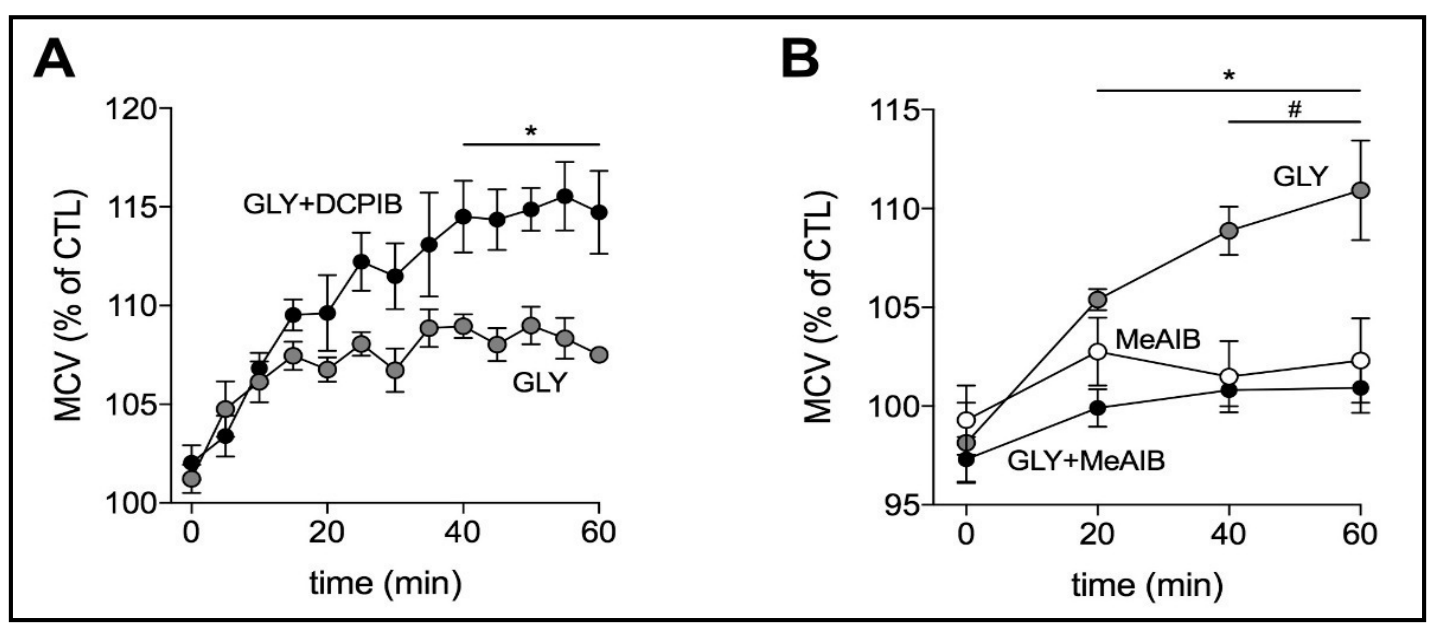

Fig. 1. Glycine-induced cell volume increase of BV-2 cells is SNAT dependent and augmented by the $\mathrm{Cl}^{-}$ channel blocker DCPIB. Mean cell volume (MCV) was measured by flow cytometry using the Coulter method. Experiments were performed under osmotically balanced (isotonic) conditions. A. Time course of glycineinduced cell swelling in absence and presence of the $\mathrm{Cl}^{-}$channel blocker DCPIB $(10 \mu \mathrm{M}){ }^{*}, \mathrm{p}<0.05$ glycine (GLY, $5 \mathrm{mM}$ ) vs. GLY+DCPIB $(10 \mu \mathrm{M}), \mathrm{n}=3-4$. B. Inhibition of glycine-induced cell swelling by the partial SNAT antagonist MeAIB (5 mM). * and *, p<0.05 GLY (5 mM) vs. GLY + MeAIB and GLY vs. MeAIB alone, respectively, $\mathrm{n}=4$. CTL, control conditions in absence of GLY, MeAIB and DCPIB. 


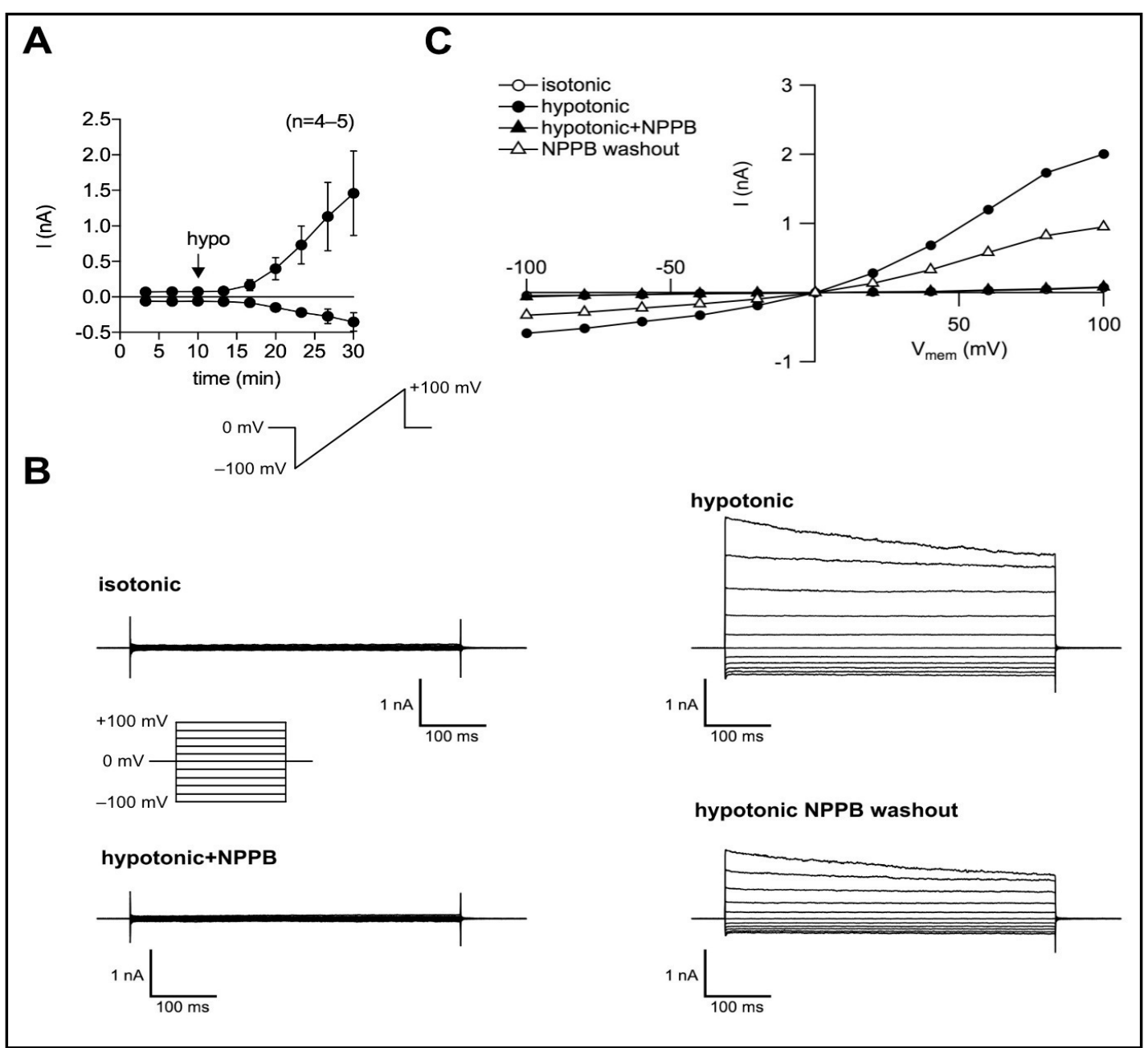

Fig. 2. Hypotonic stimulation of BV-2 cells leads to $\mathrm{ICl}_{\text {swell }}$ activation. Ruptured patch clamp recordings. A. $\mathrm{ICl}_{\text {swell }}$ activation over time. Mean whole cell currents at +100 and $-100 \mathrm{mV}$ of 4-5 individual cells evoked by $15 \%$ reduction in extracellular osmolality (hypo) recorded in response to voltage ramps (inset). B. $\mathrm{Cl}^{-}$currents of an individual cell in response to voltage steps (inset) under isotonic conditions, hypotonic conditions (showing typical outward rectification and inactivation over time at constant positive holding potentials), under hypotonic conditions in presence of NPPB $(150 \mu \mathrm{M})$ and after washout of the inhibitor. C. Current-voltage relations obtained from the tracings shown in (B).

Fig. 3 shows that hypotonic stimulation by a $30 \%$ reduction in extracellular osmolality caused a transient hyperpolarization of $\mathrm{V}_{\text {mem }}$ due to $\mathrm{K}^{+}$current activation [26, 27] from $-70.8 \pm 1.2 \mathrm{mV}$ to $-71.6 \pm 1.4 \mathrm{mV}$, followed by a slower but sustained depolarization to $-59.6 \pm$ $2.4 \mathrm{mV}$ resulting from activation of $\mathrm{ICl}_{\text {swell }}$ (Fig. 3B). This depolarization was fully reversed by the $\mathrm{ICl}_{\text {swell }}$ inhibitor DCPIB $(10 \mu \mathrm{M})$, which caused a drop in $\mathrm{V}_{\text {mem }}$ back to $-71.6 \pm 1.7 \mathrm{mV}$.

Glycine activates a Cl current under isotonic conditions $\left(\mathrm{ICl}_{\text {glycine }}\right)$ and leads to depolarization of the cell membrane potential $\left(V_{\text {mem }}\right)$

Since glycine causes cell swelling (Fig. 1), we tested whether it leads to the activation of $\mathrm{a} \mathrm{Cl}^{-}$current similar to $\mathrm{ICl}_{\text {swell }}$ As shown in Fig. 4 , addition of 1 and $5 \mathrm{mM}$ glycine elicited such a current $\left(\mathrm{ICl}_{\text {glycine }}\right)$ under isotonic conditions, which slowly developed over time becoming evident after $\sim 10 \mathrm{~min}$ and reaching a maximum after $\sim 20 \mathrm{~min}$ (Fig. 4A, D, F). Currents at -100 and $+100 \mathrm{mV}$ increased from $-64.8 \pm 4.1 \mathrm{pA}$ and $118.3 \pm 18.0 \mathrm{pA}$ to $-85.8 \pm 7.6 \mathrm{pA}$ and $222.3 \pm 49.1 \mathrm{pA}$ in the presence of $1 \mathrm{mM}$ glycine, and $-123.2 \pm 9.6 \mathrm{pA}$ and $342.5 \pm 43.3 \mathrm{pA}$ under

\section{KARGER}




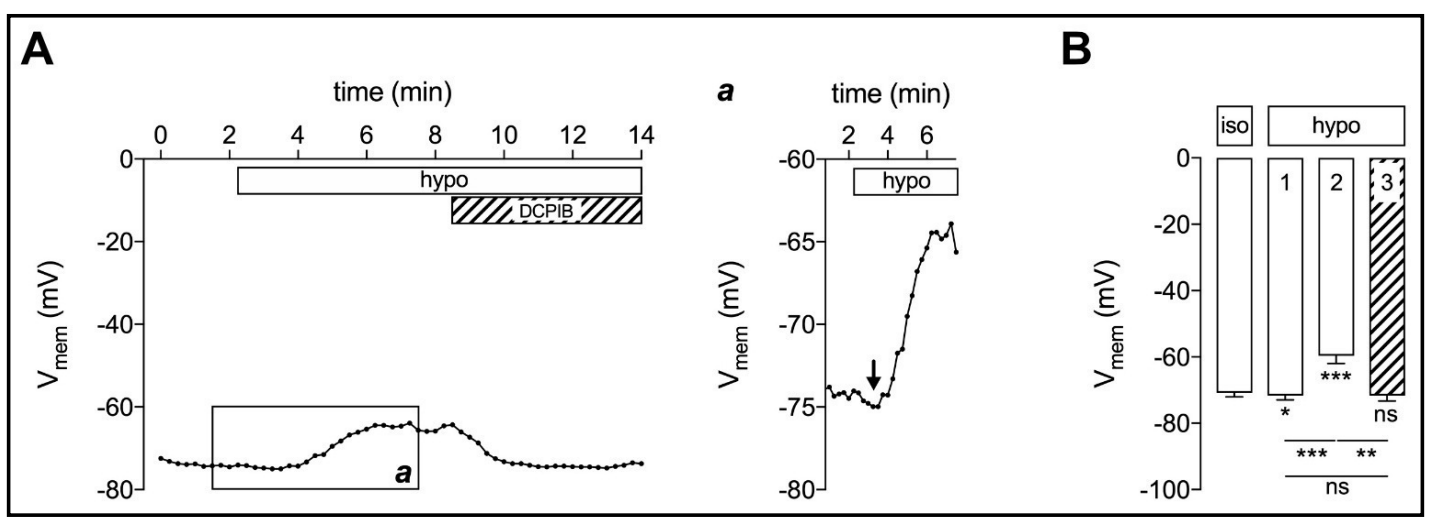

Fig. 3. Hypotonic stimulation of BV-2 cells by a $30 \%$ reduction in extracellular osmolality (hypo) causes an initial hyperpolarization followed by a sustained depolarization of $\mathrm{V}_{\mathrm{mem}}$. Perforated patch clamp recordings. A. Time course of $V_{\text {mem }}$ of a single experiment. Each dot is the mean $V_{\text {mem }}$ over $15 \mathrm{~s}$. a. Close-up of the time course. The arrow indicates the initial hyperpolarization. B. Mean $\mathrm{V}_{\text {mem }}$ under isotonic (iso) conditions $(\mathrm{n}=11)$ and under hypotonic (hypo) conditions in absence and presence of DCPIB. 1, initial hyperpolarization $(\mathrm{n}=11) ; 2$, slow $\mathrm{ICl}_{\text {swell }}$-mediated depolarization $(\mathrm{n}=11) ; 3$ (hatched bar), repolarization under DCPIB (10 $\mu \mathrm{M} ; \mathrm{n}=8) .{ }^{*}, \mathrm{p}<0.05$; $^{* *}, \mathrm{p}<0.01 ;{ }^{* * *}, \mathrm{p}<0.001 ; \mathrm{ns}$, not significant.

$5 \mathrm{mM}$ glycine (Fig. 4E). $\mathrm{ICl}_{\text {glycine }}$ showed characteristics of $\mathrm{ICl}_{\text {swell }}$ such as outward rectification, inactivation at constant positive potentials (Fig. 4B) and sensitivity to the $\mathrm{Cl}^{-}$channel blocker NPPB $(150 \mu \mathrm{M})$ (Fig. 4A, B, C, E), and the current inactivated upon withdrawal of glycine (Fig. $4 \mathrm{~F})$.

As shown in Fig. 5A-B, application of $5 \mathrm{mM}$ glycine under isotonic conditions induced a rapid depolarization of $\mathrm{V}_{\text {mem }}$ from $-64.5 \pm 5.0 \mathrm{mV}$ to $-55.2 \pm 5.1 \mathrm{mV}$ resulting from electrogenic cotransport of $\mathrm{Na}^{+}$along with glycine via SNAT [15]. Similar to glycine, glutamine (5 mM) had a reversible depolarizing effect (Fig. 5C). Additional hypotonic stimulation in continued presence of glycine caused a significant and sustained further depolarization by $\sim 7 \mathrm{mV}$ to $-48.0 \pm 4.6 \mathrm{mV}$ after a brief initial drop of $\mathrm{V}_{\text {mem }}$ by $\sim 2 \mathrm{mV}$, similar as during hypotonic stimulation alone (Fig. 3). The hypotonicity-induced depolarization was fully reverted by DCPIB $(10 \mu \mathrm{M})$, whereas the SNAT-mediated depolarization was unaffected by the $\mathrm{Cl}^{-}$channel blocker. After changing to glycine-free isotonic conditions $\mathrm{V}_{\text {mem }}$ repolarized to $-69.4 \pm 3.8 \mathrm{mV}$.

That $\mathrm{Cl}^{-}$efflux due to activation of $\mathrm{ICl}_{\text {swell }}$ further depolarized $\mathrm{V}_{\text {mem }}$ on top of the SNAT (electrogenic glycine/ $\mathrm{Na}^{+}$uptake)-mediated depolarization, was not unexpected. The question remained, however, if glycine-induced cell swelling and $\mathrm{ICl}_{\text {glycine }}$ activation alone, without additional hypotonic stimulation, affects $\mathrm{V}_{\text {mem }}$ over time. We addressed this question by performing long-time recordings under iso-osmotic conditions in the presence of $5 \mathrm{mM}$ glycine. In these experiments we observed a distinctive biphasic time course of depolarization as shown in Fig. 6: the rapid depolarization by $\mathrm{Na}^{+}$-driven glycine uptake via SNAT (from $-73.7 \pm 3.8 \mathrm{mV}$ to $-67.1 \pm 4.7 \mathrm{mV}$ ) was followed by a slow, gradual further depolarization by $\sim 20 \mathrm{mV}$ within $20-25 \mathrm{~min}$ to $-48.2 \pm 5.3 \mathrm{mV}$ that matched the time course of glycine-induced cell swelling (Fig. 1) and $\mathrm{ICl}_{\text {glycine }}$ activation (Fig. 4), and which was significantly reversed by DCPIB. After washout of DCPPIB $V_{\text {mem }}$ again strongly depolarized to $-39.5 \pm 7.1 \mathrm{mV}$.

\section{Glycine stimulates BV-2 microglial cell migration}

Ion transport, depolarization of $\mathrm{V}_{\text {mem }}$ and (sub)cellular volume regulation are critical events in the regulation of migration of microglial cells [24, 33, 39]. Since glycine modulates these events (a simplified model of these effects on cell volume and electrical properties of microglial cells is depicted in Fig. 7), we tested for the effect of glycine on BV-2 cell migration using trans-well migration system. 


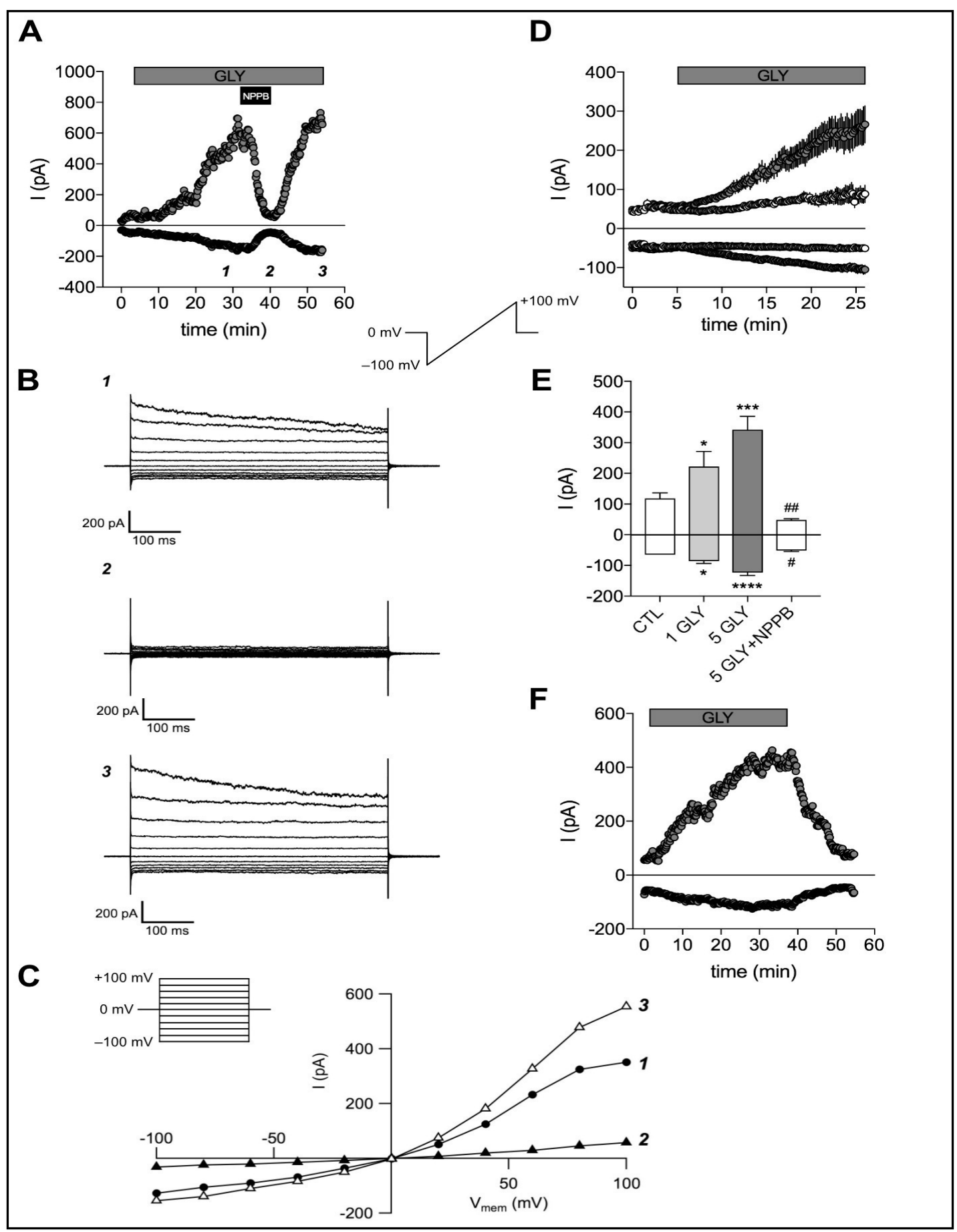

Fig. 4. Glycine evokes a $\mathrm{Cl}^{-}$current in BV-2 cells with characteristics of $\mathrm{ICl}_{\text {swell }}$. Experiments were performed under osmotically balanced (isotonic) conditions in the ruptured patch clamp configuration. A. $\mathrm{Cl}^{-}$current activation over time under $5 \mathrm{mM}$ glycine and inhibition of the current by the $\mathrm{Cl}^{-}$channel blocker NPPB. Whole cell currents at +100 and $-100 \mathrm{mV}$ in response to voltage ramps (inset). B. Currents elicited by voltage steps (inset) at time points 1-3 indicated in (A) were outwardly rectifying and inactivated over time at constant positive holding potentials $(1,3)$, and were sensitive to NPPB (2). C. Current-voltage relations obtained from the tracings shown in (B). D. Current activation in cells under $5 \mathrm{mM}$ glycine (grey circles) versus control cells kept in absence of glycine (empty circles). Mean responses of 3-32 cells. E. Mean current amplitudes after 26 min under control conditions (CTL; $n=20$ ), in presence of $1 \mathrm{mM}$ glycine ( $1 \mathrm{GLY}$; $\mathrm{n}=10$ ), $5 \mathrm{mM}$ glycine (5 GLY; $\mathrm{n}=32)$ and $5 \mathrm{GLY}+150 \mu \mathrm{M}$ NPPB $(\mathrm{n}=5)$. F. Current inactivation after withdrawal of glycine.

\section{KARGER}




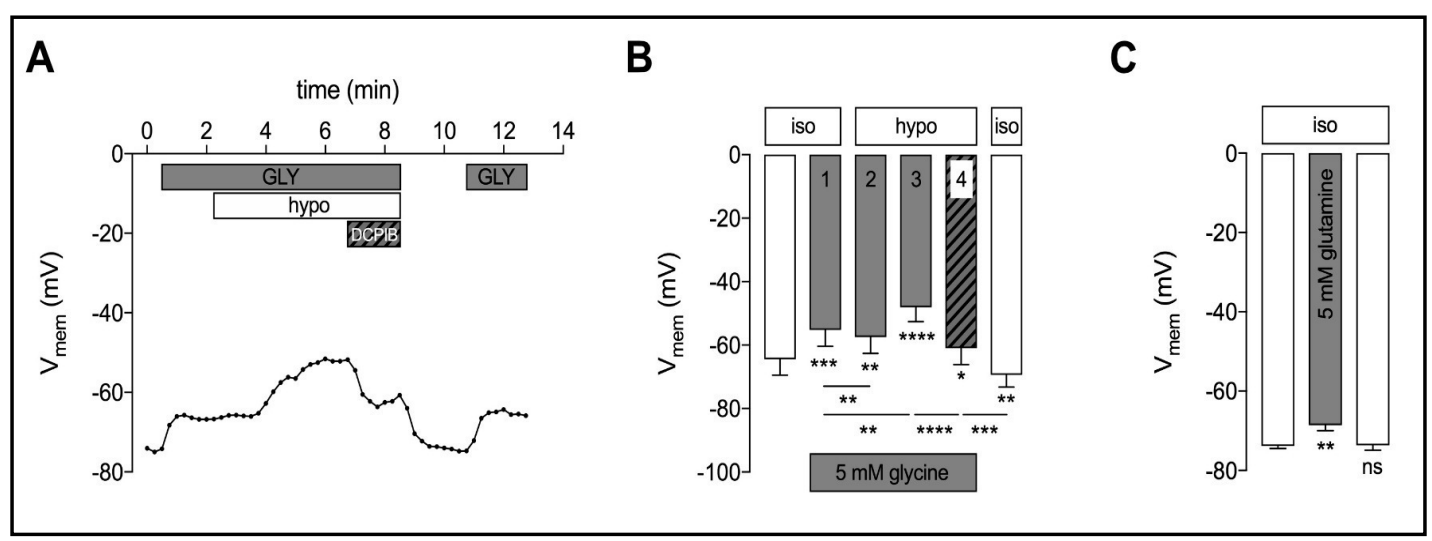

Fig. 5. $\mathrm{ICl}_{\text {swell }}$ activation by hypotonicity augments the SNAT-mediated depolarization. Perforated patch clamp recordings. A. Time course of $\mathrm{V}_{\text {mem }}$ of a single experiment (GLY, $5 \mathrm{mM}$ glycine). Each dot is the mean $\mathrm{V}_{\text {mem }}$ over $15 \mathrm{~s}$. B. Mean $\mathrm{V}_{\text {mem }}(\mathrm{n}=9)$ measured in absence (empty bars) and presence (grey bars) of $5 \mathrm{mM}$ glycine under isotonic (iso)- and hypotonic (hypo) conditions. 1, SNAT-mediated depolarization; 2, transient repolarization; 3, slow $\mathrm{ICl}_{\text {swell }}$-mediated depolarization; 4 (hatched bar), repolarization under DCPIB (10 $\mu \mathrm{M}) .^{*}, \mathrm{p}<0.05$; $^{* *}, \mathrm{p}<0.01{ }^{* * *}, \mathrm{p}<0.001 ;{ }^{* * *}, \mathrm{p}<0.0001 ;$ ns, not significant. C. Depolarization of $\mathrm{V}_{\text {mem }}$ by $5 \mathrm{mM}$ glutamine $(\mathrm{n}=5-6)$.

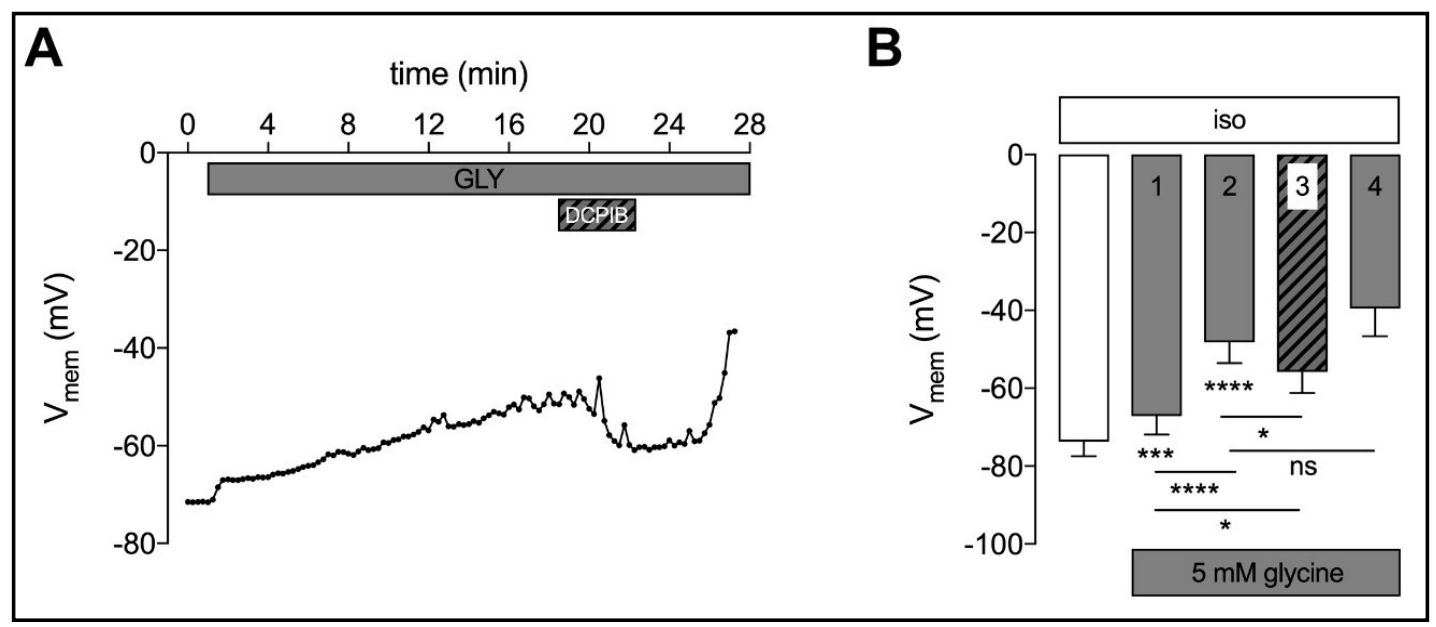

Fig. 6. Glycine depolarizes $V_{\text {mem }}$ in two phases. Experiments were performed under osmotically balanced (isotonic) conditions. Perforated patch clamp recordings. A. The time course of a single recording showed a biphasic depolarization triggered by $5 \mathrm{mM}$ glycine (GLY). The second-phase depolarization was counteracted by the $\mathrm{Cl}^{-}$channel blocker DCPIB. Each dot is the mean $\mathrm{V}_{\text {mem }}$ over $15 \mathrm{~s}$. B. Mean $\mathrm{V}_{\text {mem }}$ measured in absence (empty bars) and presence (grey bars) of $5 \mathrm{mM}$ glycine. 1, rapid SNAT-mediated depolarization ( $\mathrm{n}=15) ; 2$, slow $\mathrm{ICl}_{\text {glycine }}$-mediated depolarization ( $\left.\mathrm{n}=15\right) ; 3$ (hatched bar), repolarization under DCPIB (10 $\left.\mu \mathrm{M} ; \mathrm{n}=15\right)$; 4, depolarization after DCPIB washout $(n=9)$. $^{*}, \mathrm{p}<0.05$; ${ }^{* *}, \mathrm{p}<0.001 ;{ }^{* * * *}, \mathrm{p}<0.0001$; ns, not significant.

As shown in Fig. 8, migratory activity was significantly increased by $45 \%$ under $5 \mathrm{mM}$ glycine compared to control conditions (serum-free medium). The SNAT antagonist MeAIB $(5 \mathrm{mM}$ ) attenuated the effect of $5 \mathrm{mM}$ glycine, suggesting that the stimulatory effect of glycine is SNAT-dependent. In culture medium containing $10 \% \mathrm{FCS}, 0.5 \mu \mathrm{g} / \mathrm{ml} \mathrm{LPS}$, or $1 \mu \mathrm{M}$ ATP the migratory activity was increased by $\sim 81 \%, 56 \%$ and $74 \%$, respectively. 


\section{Cellular Physiology Cell Physiol Biochem 2018;50:1460-1473 and Biochemistry \begin{tabular}{l|l} 
DOl: 10.1159/000494646 & $\begin{array}{l}\text { O 2018 The Author(s). Published by S. Karger AG, Basel } \\
\text { www.karger.com/cpb }\end{array}$
\end{tabular}

Fig. 7. Hypothetical (simplified) model of the effects of glycine on cell volume and electrical properties of microglial cells. The electrogenic uptake of glycine by a $\mathrm{Na}^{+}$-coupled cotransport via SNAT leads to a rapid depolarization of $V_{\text {mem }}$ and increases the intracellular osmolality. The osmotically obliged water influx causes cell swelling and activates swelling dependent $\mathrm{Cl}^{-}$ channels/currents $\left(\mathrm{ICl}_{\text {glycine }} / \mathrm{ICl}_{\text {swell }}\right)$, which further depolarizes $V_{\text {mem }}$ and back-regulates cell volume by regulatory volume decrease (RVD).

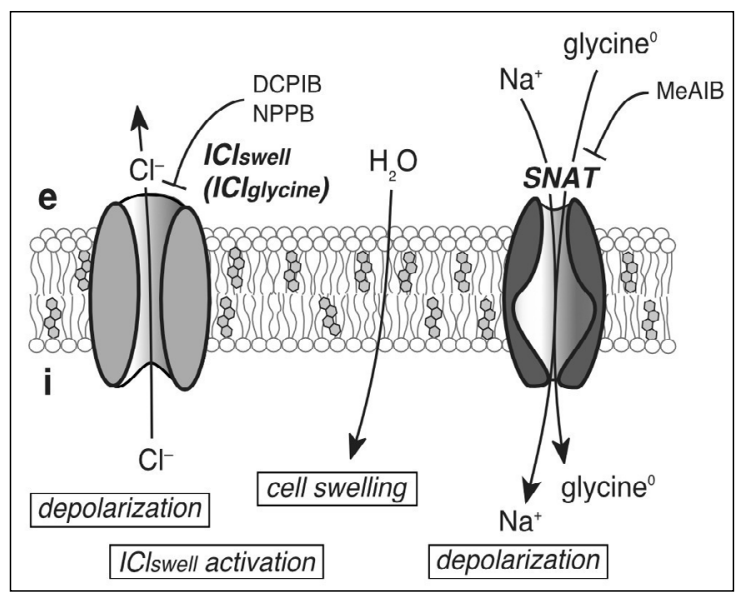

\section{Discussion}

This study confirms previous findings showing that the amino acid glycine - a widely distributed neurotransmitter in the CNS causes depolarization of the cell membrane potential and cell swelling in microglial BV-2 cells [15]. These effects are mediated by electrogenic uptake of $\mathrm{Na}^{+}$and glycine via the sodium-dependent neutral amino acid transporter (SNAT). In a recent study we have shown, that glycine facilitates phagocytosis and that this process is dependent on glycineinduced cell swelling [15]. These findings were fostered by an earlier study showing that in phagocytosing microglial cells a distinctive $\mathrm{Cl}^{-}$conductance, which is activated to drive regulatory volume decrease (RVD) after cell swelling and which gives rise to the swelling-activated $\mathrm{Cl}^{-}$current $\mathrm{ICl}_{\text {swell }}\left(\mathrm{ICl}_{\text {vol }}\right.$ VRAC, VSOR), is increased. Accordingly, phagocytosis was suppressed by inhibitors of $\mathrm{Cl}^{-}$channels and by counteracting glycine-

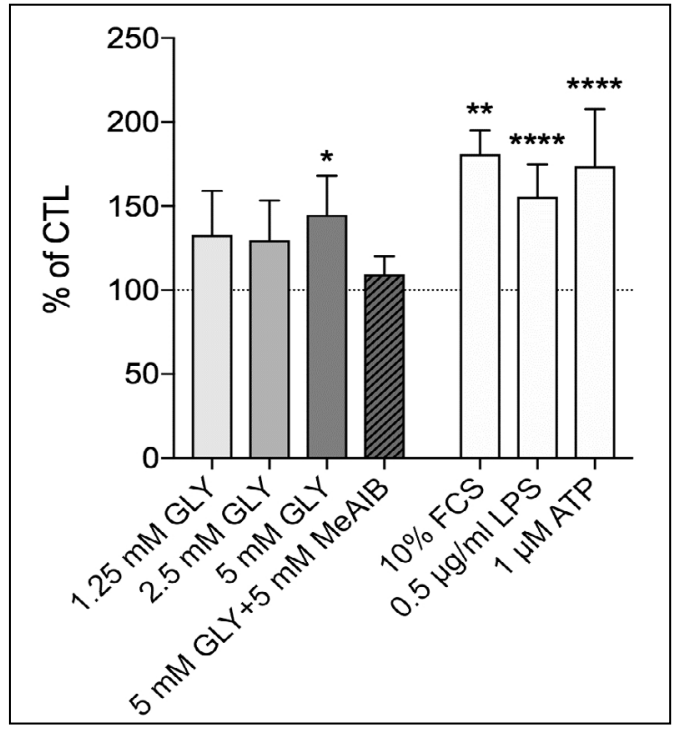

Fig. 8. Glycine-stimulated migration in BV-2 cells $(\mathrm{n}=3-11)$. Control values (CTL; set to $100 \%)$ are indicated by the dashed line. GLY, glycine; LPS, lipopolysaccharide. ${ }^{*}, \mathrm{p}<0.05 ;{ }^{* *}, \mathrm{p}<0.01 ; * * * *$ $\mathrm{p}<0.0001$. induced cell swelling through MeAIB $[15,35]$.

It remained unclear, however, whether the activation of $\mathrm{ICl}_{\text {swell }}$ occurs as a consequence of phagocytosis per se or/and as a consequence of SNAT-mediated cellular uptake of $\mathrm{Na}^{+}$and glycine and the osmotically driven influx of water.

In our study, glycine increased the mean cell volume (MCV) by $~ 7 \%$ compared to a $\sim 17 \%$ volume increase observed in EATCs [20]. In both cell types a plateau of the MCV was slowly reached after 15-30 min and in both microglial cells and EATCs, cell swelling was prevented in $\mathrm{Na}^{+}$free extracellular saline $[15,20]$. The inhibition of glycine-induced cell swelling by the partial SNAT antagonist MeAIB, as shown here, indicates that the activity of this $\mathrm{Na}^{+}$coupled cotransporter underlies cell swelling. In line with this assumption, it has been reported that the transport A system, which includes SNAT, participates in cell volume regulation [40] and that in human fibroblasts SNAT2 silencing lowers the intracellular concentration of amino acids and inhibits the regulatory volume increase (RVI) after hypertonic stress [41].

$\mathrm{Na}^{+}$and glycine uptake via SNAT is followed by the activation of a $\mathrm{Cl}^{-}$current under isotonic conditions $\left(\mathrm{ICl}_{\text {glvcine }}\right)$. This current resembles the one elicited in $\mathrm{BV}-2$ cells by hypotonic cell swelling $\left(\mathrm{ICl}_{\text {swell, }}\right.$ VRAC, VSOR), i.e.; outward rectification, time-dependent inactivation at 
constant positive holding potentials and sensitivity to the $\mathrm{Cl}^{-}$channel blockers NPPB and DCPIB [15]. In monocytes and Kupffer cells, a glycine-dependent $\mathrm{Cl}^{-}$current is assigned to the ionotropic glycine receptor (GlyR) $[12,13]$ and glycine binding increases its intrinsic $\mathrm{Cl}^{-}$conductance which leads to a hyperpolarization due to $\mathrm{Cl}^{-}$influx $[13,16,42]$. Based on electrophysiological recordings, Schilling and Eder [14] convincingly argued against GlyR expression in BV-2 cells. In line with our previous results [15], they found that glycine caused a rapid and sustained depolarization, which was insensitive to the GlyR antagonist strychnine. In addition, the glycine-induced depolarization was $\mathrm{Na}^{+}$dependent and suppressed by MeAIB [14]. In line with this finding, our earlier results from RT-PCR analysis cells did not reveal expression of GlyR (isoforms Glra1-4) in BV-2 cells and primary microglial cells, but detected those for the $\mathrm{Na}^{+}$-coupled neutral amino acid transporter SNAT (solute carrier family 38 isoforms Slc38a1, 2 and 4) [15]. Therefore, the glycine-induced $\mathrm{Cl}^{-}$current $\left(\mathrm{ICl}_{\text {glycine }}\right)$ observed here is clearly independent of GlyR. Apart from this, the biophysical properties of $\mathrm{ICl}_{\text {glycine }}$ are different from GlyR-mediated $\mathrm{Cl}^{-}$currents [43], but they are identical to those of swelling-activated $\mathrm{Cl}^{-}$currents $\left(\mathrm{ICl}_{\text {swell, }} \mathrm{ICl}_{\text {vol }}\right.$, VRAC) described in microglial cells and in a plenitude of other cells $[26,27,33,44,45]$.

Glycine-induced cell swelling was enhanced by the $\mathrm{Cl}^{-}$channel blocker DCPIB. This indicates that the activation of $\mathrm{ICl}_{\text {glycine }} / \mathrm{ICl}_{\text {swell }}$ limits further cell swelling upon amino acid and $\mathrm{Na}^{+}$uptake. However, the blocker does not affect the initial kinetics of glycine-induced cell swelling, which is most likely due to the delayed onset of $\mathrm{Cl}^{-}$current activation. Indeed, $\mathrm{ICl}_{\text {glycine }}$ activation and depolarization of $\mathrm{V}_{\text {mem }}$ evolve with a considerable delay of several minutes after administration of the amino acid, which is similar to the delayed activation of $\mathrm{ICl}_{\text {swell }}$ by hypotonic stimulation $[35,44]$. The changes in $\mathrm{V}_{\text {mem }}$ caused by glycine were biphasic. Shortly after addition of the amino acid a rapid and stable depolarization occurred. We and others found that this depolarization was reversed by a $\mathrm{Na}^{+}$-free extracellular solution [14, 15], showing that this initial depolarization is due to electrogenic glycine uptake along with $\mathrm{Na}^{+}$via SNAT. The application of glutamine instead of glycine similarly depolarizes $\mathrm{V}_{\text {mem }}$. In the second phase, a further depolarization set in with a delay of 5-10 min, which was antagonized by DCPIB. This supports our assumption that this second-phase depolarization is indeed caused by delayed activation of $\mathrm{ICl}_{\text {glycine }} / \mathrm{ICl}_{\text {swell }}$ over time during glycine-induced cell swelling. That $\mathrm{ICl}_{\text {swell }}$ activation affects $\mathrm{V}_{\text {mem }}$ in BV-2 cells is evident from depolarizations observed upon hypotonic cell swelling both in absence and presence of glycine, which were reversed by DCPIB.

Cytoskeletal rearrangements as well as ion and water fluxes through ion channels, transporters and aquaporins are basic requirements for cell migration and there is a mutual interaction between these factors. In migrating cells, channels and transporters show a functionally polarized distribution and migrating cells undergo repetitive cycles of local volume gain at the cell front and a volume loss in the rear part. $\mathrm{ICl}_{\text {swell }}$ plays a key role in the retraction of the trailing edge by mediating $\mathrm{Cl}^{-}$efflux, which drives the efflux of water (reviewed in $[24,33,39]$ ). The depolarization of the cell membrane potential due to $\mathrm{Cl}^{-}$ efflux generates a driving force for the movement of other ions affecting migration. Blocking these $\mathrm{Cl}^{-}$channels has been found to inhibit migration in several cell types including human malignant glioma cells, nasopharyngeal glioma cells, HeLa cells and microglial cells [46-49]. Given the effects of glycine on hallmarks of cell migration (cell swelling, $\mathrm{Cl}^{-}$current activation, depolarization of $\mathrm{V}_{\mathrm{mem}}$ ) we investigated if glycine modulates the migratory activity of microglial cells. Escherichia coli bacteria have been shown to be attracted by several amino acids including glycine [50] and glycine in combination with gastrin (glycine-extended gastrin) has been found to stimulate gastrointestinal cell migration [51]. We found that $5 \mathrm{mM}$ glycine significantly increased BV-2 cell migration. To our knowledge, this is the first study showing that glycine stimulates migration in microglial cells. The stimulatory effect of glycine on migration was abrogated by the SNAT inhibitor MeAIB. Similarly, we could previously show that phagocytosis in microglial cells is suppressed by MeAIB [34]. This shows that SNATs play a central role in mediating the effects of glycine on migration and phagocytosis in these cells and suggests that movement of the entire cell during migration and the movement 
of the pseudopodium to entangle a cell during phagocytosis are similar processes, which are closely linked to cell volume regulatory mechanisms. In the CNS, the role of glycine as a chemoattractant might be particularly relevant in case of traumata, stroke, ischemia and reperfusion injury or neurodegeneration, when dying neurons and glial cells release glycine and other intracellular compounds. In such a scenario, when released compounds accumulate in the restricted interstitial space, glycine might act as a chemoattractant and guide microglial cells to these regions and concurrently stimulate their phagocytotic activity to remove cell debris and pathogens.

\section{Conclusion}

We conclude that the exposure of glycine to microglial BV-2 cells leads to an uptake of glycine by a $\mathrm{Na}^{+}$-coupled cotransport system (SNAT), which causes (1) cell membrane depolarization, (2) cell swelling due to osmotically driven water influx, and, (3) activation of a swelling-dependent $\mathrm{Cl}^{-}$current, which further depolarizes $\mathrm{V}_{\text {mem }}$. Moreover, we conclude that glycine acts as a chemoattractant and stimulates migration of microglial cells.

\section{Abbreviations}

SNAT (sodium neutral amino acid transporter); RVD (regulatory volume decrease); RVI (regulatory volume increase); MeAIB ( $\alpha$-(Methylamino)isobutyric acid); GlyR (glycine receptor); $\mathrm{ICl}_{\text {swell }}$ (swelling dependent chloride current); VSOR (volume-sensitive outwardly rectifying); VRAC (volume-regulated anion channel); DCPIB (4-[(2-Butyl-6, 7-dichloro-2-cyclopentyl-2, 3-dihydro-1-oxo-1H-inden-5-yl)oxy]butanoic acid); DIDS ((4, 4'-Diisothiocyanato-2, 2'-stilbenedisulfonic acid)); NPPB (5-Nitro-2-(3-phenylpropylamino) benzoic acid).

\section{Acknowledgements}

We thank Julia Landrichinger, Karin Oberascher-Holzinger and Leman Emin for the skilled technical and administrative assistances. This project was supported by the research support funds of the Paracelsus Medical University, grant R-15/05/073-KIT to MK.

\section{Disclosure Statement}

The authors declare that there are no conflicts of interest.

\section{References}

1 Aprison MH, Shank RP, Davidoff RA, R. Werman R: The distribution of glycine, a neurotransmiter suspect in the central nervous system of several vertebrate species, 1968.

2 Beato M: The Time Course of Transmitter at Glycinergic Synapses onto Motoneurons. J Neurosci 2008;28:7412-7425.

3 Xu TL, Gong N: Glycine and glycine receptor signaling in hippocampal neurons: diversity, function and regulation. Prog Neurobiol 2010;91:349-361.

4 Van Hove J, Coughlin C, II, Scharer G: Glycine Encephalopathy; in (Adam MP, Ardinger HH, Pagon RA, Wallace SE, Bean LJH, Stephens K, and Amemiya A, eds) GeneReviews((R)). Seattle (WA), 1993, vol. p.^pp.

5 Guerra-Romero L, Tureen JH, Fournier MA, Makrides V, Tauber MG: Amino acids in cerebrospinal and brain interstitial fluid in experimental pneumococcal meningitis. Pediatr Res 1993;33:510-513. 


\section{Cellular Physiology Cell Physiol Biochem 2018;50:1460-1473

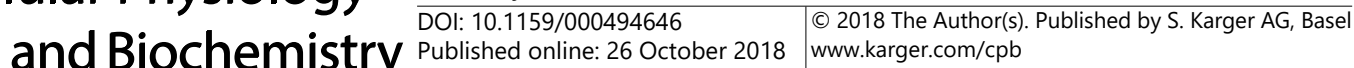

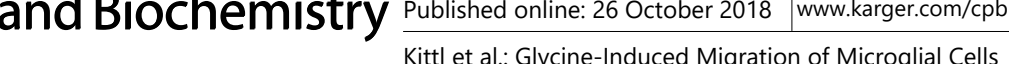

6 Perry TL, Krieger C, Hansen S, Eisen A: Amyotrophic lateral sclerosis: amino acid levels in plasma and cerebrospinal fluid. Ann Neurol 1990;28:12-17.

7 Barkhatova VP, Zavalishin IA, Askarova L, Shavratskii V, Demina EG: Changes in neurotransmitters in multiple sclerosis. Neurosci Behav Physiol 1998;28:341-344.

-8 Ikejima K, Iimuro Y, Forman DT, Thurman RG: A diet containing glycine improves survival in endotoxin shock in the rat. Am J Physiol 1996;271:G97-103.

-9 Yin M, Ikejima K, Arteel GE, Seabra V, Bradford BU, Kono H, Rusyn I, Thurman RG: Glycine accelerates recovery from alcohol-induced liver injury. J Pharmacol Exp Ther 1998;286:1014-1019.

10 Rose ML, Madren J, Bunzendahl H, Thurman RG: Dietary glycine inhibits the growth of B16 melanoma tumors in mice. Carcinogenesis 1999;20:793-798.

-11 Rose ML, Cattley RC, Dunn C, Wong V, Li X, Thurman RG: Dietary glycine prevents the development of liver tumors caused by the peroxisome proliferator WY-14, 643. Carcinogenesis 1999;20:2075-2081.

$\checkmark 12$ Spittler A, Reissner CM, Oehler R, Gornikiewicz A, Gruenberger T, Manhart N, Brodowicz T, Mittlboeck M, Boltz-Nitulescu G, Roth E: Immunomodulatory effects of glycine on LPS-treated monocytes: reduced TNFalpha production and accelerated IL-10 expression. FASEB J 1999;13:563-571.

13 Wheeler MD, Thurman RG: Production of superoxide and TNF-alpha from alveolar macrophages is blunted by glycine. Am J Physiol 1999;277:L952-959.

14 Schilling T, Eder C: A novel physiological mechanism of glycine-induced immunomodulation: $\mathrm{Na}^{+}$-coupled amino acid transporter currents in cultured brain macrophages. J Physiol 2004;559:35-40.

15 Komm B, Beyreis M, Kittl M, Jakab M, Ritter M, Kerschbaum HH: Glycine modulates membrane potential, cell volume, and phagocytosis in murine microglia. Amino Acids 2014;46:1907-1917.

-16 Rajendra S, Lynch JW, Schofield PR: The glycine receptor. Pharmacol Ther 1997;73:121-146.

17 Steeves CL, Hammer MA, Walker GB, Rae D, Stewart NA, Baltz JM: The glycine neurotransmitter transporter GLYT1 is an organic osmolyte transporter regulating cell volume in cleavage-stage embryos. Proc Natl Acad Sci U S A 2003;100:13982-13987.

-18 Steeves CL, Baltz JM: Regulation of intracellular glycine as an organic osmolyte in early preimplantation mouse embryos. J Cell Physiol 2005;204:273-279.

-19 Dawson KM, Collins JL, Baltz JM: Osmolarity-dependent glycine accumulation indicates a role for glycine as an organic osmolyte in early preimplantation mouse embryos. Biol Reprod 1998;59:225-232.

20 Hudson RL, Schultz SG: Sodium-coupled glycine uptake by Ehrlich ascites tumor cells results in an increase in cell volume and plasma membrane channel activities. Proc Natl Acad Sci U S A 1988;85:279-283.

21 Maallem S, Mutin M, Gonzalez-Gonzalez IM, Zafra F, Tappaz ML: Selective tonicity-induced expression of the neutral amino-acid transporter SNAT2 in oligodendrocytes in rat brain following systemic hypertonicity. Neuroscience 2008;153:95-107.

22 Franchi-Gazzola R, Dall’Asta V, Sala R, Visigalli R, Bevilacqua E, Gaccioli F, Gazzola GC, Bussolati O: The role of the neutral amino acid transporter SNAT2 in cell volume regulation. Acta Physiol (Oxf) 2006;187:273283.

-23 Kettenmann H, Hanisch UK, Noda M, Verkhratsky A: Physiology of microglia. Physiol Rev 2011;91:461-553.

-24 Schwab A, Fabian A, Hanley PJ, Stock C: Role of ion channels and transporters in cell migration. Physiol Rev 2012;92:1865-1913.

-25 Schneider SW, Pagel P, Rotsch C, Danker T, Oberleithner H, Radmacher M, Schwab A: Volume dynamics in migrating epithelial cells measured with atomic force microscopy. Pflugers Arch 2000;439:297-303.

-26 Lang F, Busch GL, Ritter M, Volkl H, Waldegger S, Gulbins E, Haussinger D: Functional Significance of Cell Volume Regulatory Mechanisms. Physiol Rev 1998;78:247-306.

-27 Hoffmann EK, Lambert IH, Pedersen SF: Physiology of cell volume regulation in vertebrates. Physiol Rev 2009;89:193-277.

28 Schwab A: Function and spatial distribution of ion channels and transporters in cell migration. Am J Physiol Renal Physiol 2001;280:F739-747.

29 Schwab A, Wulf A, Schulz C, Kessler W, Nechyporuk-Zloy V, Romer M, Reinhardt J, Weinhold D, Dieterich P, Stock C, Hebert SC: Subcellular distribution of calcium-sensitive potassium channels (IK1) in migrating cells. J Cell Physiol 2006;206:86-94.

-30 Mao JW, Wang LW, Jacob T, Sun XR, Li H, Zhu LY, Li P, Zhong P, Nie SH, Chen LX: Involvement of regulatory volume decrease in the migration of nasopharyngeal carcinoma cells. Cell Res 2005;15:371-378. 


\section{Cellular Physiology Cell Physiol Biochem 2018;50:1460-1473 \begin{tabular}{ll|l} 
DOl: 10.1159/000494646 & $\begin{array}{l}\text { O 2018 The Author(s). Published by S. Karger AG, Basel } \\
\text { www.karger.com/cpb }\end{array}$
\end{tabular}}

Kittl et al.: Glycine-Induced Migration of Microglial Cells

-31 Klein M, Seeger P, Schuricht B, Alper SL, Schwab A: Polarization of $\mathrm{Na}^{+} / \mathrm{H}^{+}$and $\mathrm{Cl} / \mathrm{HCO}_{3}^{-}$exchangers in migrating renal epithelial cells. J Gen Physiol 2000;115:599-608.

-32 Haas BR, Sontheimer H: Inhibition of the Sodium-Potassium-Chloride Cotransporter Isoform-1 reduces glioma invasion. Cancer Res 2010;70:5597-5606.

-33 Jakab M, Ritter M: Cell volume regulatory ion transport in the regulation of cell migration. Contrib Nephrol 2006;152:161-180.

-34 Furtner T, Zierler S, Kerschbaum HH: Blockade of chloride channels suppresses engulfment of microspheres in the microglial cell line, BV-2. Brain Res 2007;1184:1-9.

-35 Harl B, Schmolzer J, Jakab M, Ritter M, Kerschbaum HH: Chloride Channel Blockers Suppress Formation of Engulfment Pseudopodia in Microglial Cells. Cell Physiol Biochem 2013;31:319-337.

-36 Warskulat U, Zhang F, Haussinger D: Modulation of phagocytosis by anisoosmolarity and betaine in rat liver macrophages (Kupffer cells) and RAW 264.7 mouse macrophages. FEBS Lett 1996;391:287-292.

-37 Yamamoto S, Ishihara K, Ehara T, Shioya T: Cell-volume regulation by swelling-activated chloride current in guinea-pig ventricular myocytes. Jpn J Physiol 2004;54:31-38.

-38 Eggermont J, Trouet D, Carton I, Nilius B: Cellular function and control of volume-regulated anion channels. Cell Biochem Biophys 2001;35:263-274.

39 Schwab A, Nechyporuk-Zloy V, Fabian A, Stock C: Cells move when ions and water flow. Pflugers Arch 2007;453:421-432.

40 Mackenzie B, Erickson JD: Sodium-coupled neutral amino acid (System N/A) transporters of the SLC38 gene family. Pflugers Arch 2004;447:784-795.

-41 Bevilacqua E, Bussolati O, Dall'Asta V, Gaccioli F, Sala R, Gazzola GC, Franchi-Gazzola R: SNAT2 silencing prevents the osmotic induction of transport system A and hinders cell recovery from hypertonic stress. FEBS Lett 2005;579:3376-3380.

42 Wheeler MD, Ikejema K, Enomoto N, Stacklewitz RF, Seabra V, Zhong Z, Yin M, Schemmer P, Rose ML, Rusyn I, Bradford B, Thurman RG: Glycine: a new anti-inflammatory immunonutrient. Cell Mol Life Sci 1999;56:843-856.

43 Raltschev C, Hetsch F, Winkelmann A, Meier JC, Semtner M: Electrophysiological Signature of Homomeric and Heteromeric Glycine Receptor Channels. J Biol Chem 2016;291:18030-18040.

44 Schlichter LC, Mertens T, Liu B: Swelling activated $\mathrm{Cl}^{-}$channels in microglia: Biophysics, pharmacology and role in glutamate release. Channels (Austin) 2011;5:128-137.

45 Kinard TA, Satin LS: An ATP-sensitive $\mathrm{Cl}^{-}$channel current that is activated by cell swelling, cAMP, and glyburide in insulin-secreting cells. Diabetes 1995;44:1461-1466.

46 Mao J, Chen L, Xu B, Wang L, Wang W, Li M, Zheng M, Li H, Guo J, Li W, Jacob TJ, Wang L: Volume-activated chloride channels contribute to cell-cycle-dependent regulation of HeLa cell migration. Biochem Pharmacol 2009;77:159-168.

47 Mao J, Wang L, Fan A, Wang J, Xu B, Jacob TJ, Chen L: Blockage of volume-activated chloride channels inhibits migration of nasopharyngeal carcinoma cells. Cell Physiol Biochem 2007;19:249-258.

48 Soroceanu L, Manning TJ, Jr., Sontheimer H: Modulation of glioma cell migration and invasion using $\mathrm{Cl}^{-}$and $\mathrm{K}^{+}$ion channel blockers. J Neurosci 1999;19:5942-5954.

$\checkmark 49$ Zierler S, Frei E, Grissmer S, Kerschbaum HH: Chloride influx provokes lamellipodium formation in microglial cells. Cell Physiol Biochem 2008;21:55-62.

50 Mesibov R, Adler J: Chemotaxis toward amino acids in Escherichia coli. J Bacteriol 1972;112:315-326.

-51 He H, Pannequin J, Tantiongco JP, Shulkes A, Baldwin GS: Glycine-extended gastrin stimulates cell proliferation and migration through a Rho- and ROCK-dependent pathway, not a Rac/Cdc42-dependent pathway. Am J Physiol Gastrointest Liver Physiol 2005;289:G478-488. 